\title{
Effect of Different Methods of Bone Preparation on the Skeleton of the African Giant Pouched Rat (Cricetomys gambianus)
}

\author{
Efecto de Diferentes Métodos de Preparación Ósea en el \\ Esqueleto de la Rata Gigante Africana (Cricetomys gambianus)
}

Kenechukwu Tobechukwu Onwuama; Sulaiman Olawoye Salami; Magdaline Ali \& James Oliver Nzalak

ONWUAMA, K. T.; SALAMI, S. O.; ALI, O. \& NZALAK, J. O. Effect of different methods of bone preparation on the skeleton of the african giant pouched rat (Cricetomys gambianus). Int. J. Morphol., 30(2):425-427, 2012.

SUMMARY: This study was conducted using 12 Adult African Giant Pouched rats of both sexes to compare and to see the effect of three different methods of bone preparation on the bones of the African Giant Rat (Cricetomys gambianus). Five rats were used for maceration method, three for burial method and four rats for chemical method (involving two rats each for 3\% and 5\% solution of Sodium Hydroxide). Chemical preparation with Sodium Hydroxide was found to be the best method in terms of time required to complete the procedure, number of bones recovered, colour of the bones and odour of the preparation. However, the chemical method has the disadvantage of dissolving and cracking the bones if the concentration used is high and prompt attention is not given to the preparation.

KEY WORDS: Bone preparation; African Giant Pouched Rat; Chemical preparation; Maceration.

\section{INTRODUCTION}

Preparation of bones involve soft tissue removal or bone cleaning, bone bleeching, bone articulation and labelling. Depending on the size of the animal, each of the preceeding processes may vary in the amount of time required (Boyle, 2010). There are a variety of methods or techniques used in bone preparation (Dawson, 1926). This includes maceration of dissected carcass through submersion in water for a period of time, burying on the ground, as well as boiling in hot water. Other methods of bone preparation are introduction of enzymes or chemicals to fasten the removal of the attached soft tissues from the bones.

Preparation of bones from carcasses by maceration has been shown to elicit strong and distasteful odours, is time consuming and takes longer time in large animals (Grygon 2010; The Bone Room, 2006). In small animals, preparation of bones by Dermestes the flesh eating beetle, has been used and is said to be the best method (Borell, 1947; Hall \& Russell, 1933). It is with this background information that three methods of bone preparation were employed so as to compare the suitability of these methods and their effects on the preparation of bones of the African Giant Pouched Rat.

\section{MATERIAL AND METHOD}

Acquisition of experimental animals. A total of 12 adult African giant pouched rats Cricetomys gambianus of both sexes were captured alive in the wild around Samaru villages in Zaria, Kaduna state, Nigeria using metal cage traps. They were housed in customized laboratoey rat cages in the department of Veterinary anatomy laboratory, faculty of veterinary medicine, Ahmadu Bello University zaria, Nigeria and fed with fruits, groundnut pellets and water ad libitum for a week prior to commencement of study (Ewer, 1967; Ajayi, 1975; Perry et al., 2006).

\section{Preparation of Bones}

Maceration method: Five rats ( 4 males, 1 female) were euthanized using gaseous chloroform in a confined container and weighed using a balance (Emperor Model p.1210) with a sensitivity of $0.1 \mathrm{~g}$. The weight of each rat was recorded. They were then dissected to remove skin, thoracic, abdominal and pelvic contents. The muscles were carefully dissected and teased from the bones to leave the bones with minimal soft tissue attachments. They were then put into different plastic buckets containing water enough to submerge the bones. The plastic buckets were then covered 


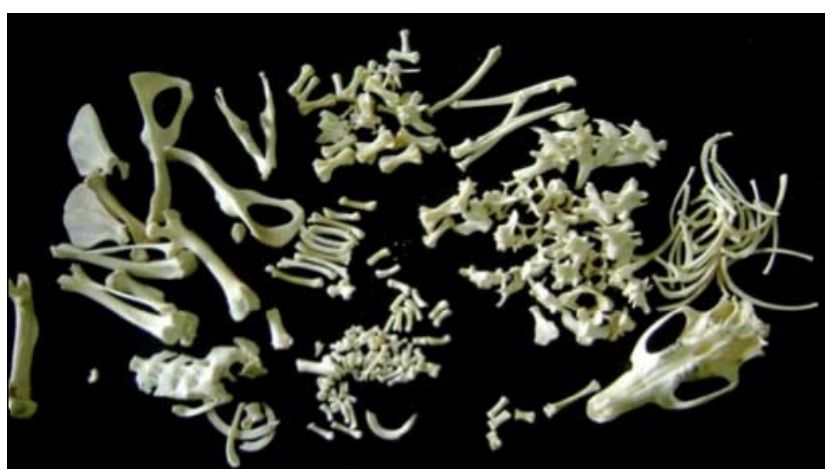

Fig. 1. Macerated bones showing white colour of bones of the African Giant Pouched Rat.

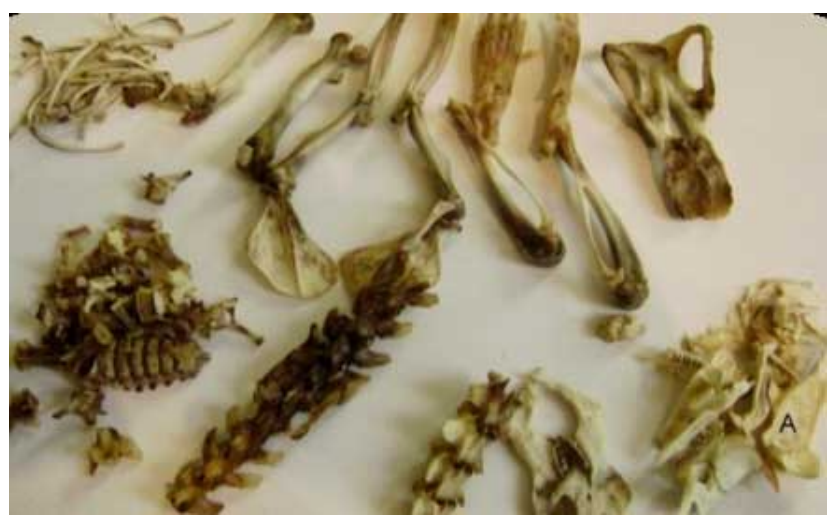

Fig. 3. Sodium hydroxide (5\%) prepared bones showing whitebrown colour of bones of the African Giant Rat.

and placed under the sun for four days after which the water was drained and the bones recovered and dried.

Burial method: Three rats ( 2 males, 1 female) were euthanized using gaseous chloroform in a confined container and weighed as done for the previous ones. The weight of each rat was also recorded. The rats were buried and the bones recovered after five days. The recovered bones were washed to remove attached soil and dried.

Chemical (Sodium hydroxide) method: Four rats (2 males, 2 females) were euthanized using the aforementioned method and weighed accordingly. Thereafter, the rats were carefully dissected to remove as much soft tissue as possible from the bones. Then the partially cleaned bones were immersed in plastic buckets containing 3\% and 5\% solution of $\mathrm{NaOH}$ (one male and a female in each solution). The plastic buckets were then placed under the sun and checked every 30 minutes to recover the bones as they are freed from the flesh in order to avoid digestion of the bones by the Sodium hydroxide $(\mathrm{NaOH})$. The macerated bones were then washed in running water and air dried under the fan.

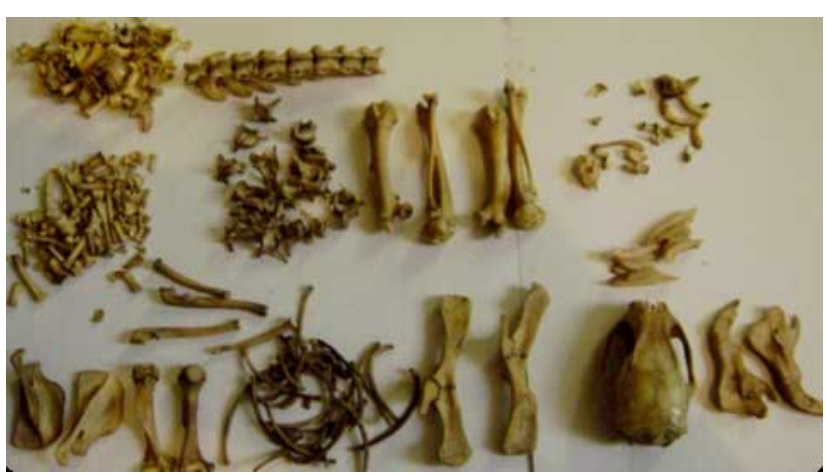

Fig. 2. Buried bones showing brown colour of bones of the African Giant pouched rat.

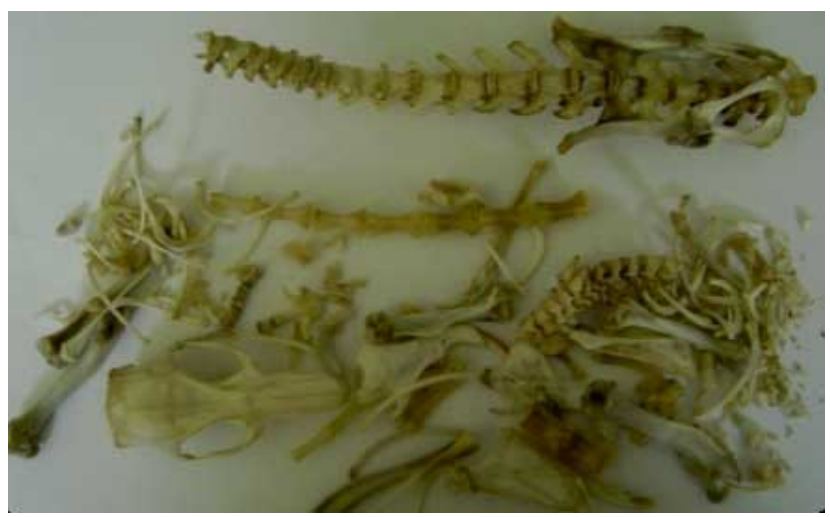

Fig. 4. Sodium hydroxide (3\%) prepared bones showing creamy colour of bones of the African Giant Rat.

The number of days it took for complete preparation to occur in each of the three methods used was recorded. Parameters such as colour change and odour of the bones were noted. Percentage of bone recovery was noted and thereafter photographs of the bones were taken.

\section{RESULTS AND DISCUSSION}

The results of the effects of the three methods of bone preparation on the African Giant Rat employed in this study signify that the best method suitable for bone preparation in this animal is preparation by use of chemical (in this case Sodium hydroxide) (Tables I and II; Figs. 1-4). The method is not time consuming, bones appear creamy (Fig. 4) which can be whitened with other chemicals like Hydrogen peroxide, the smell of the bones and the process is not as strong and distasteful as perceived in the other two methods and almost all bones are recovered with proper care. The main disadvantage of this process is the cracks made on the bones (Table II). This can be prevented or reduced by reducing the concentration of the chemical and the exposure 
Table I. Comparison of results from the three methods of bone preparation employed.

\begin{tabular}{lcccc}
\hline Parameters & Maceration & Burial & \multicolumn{2}{c}{ Sodium hydroxide } \\
\cline { 4 - 5 } & & & $\mathbf{5 \%}$ conc. & $\mathbf{3 \%}$ conc. \\
\hline Days taken & 4 days & 5 days & 6 hours & 7 hours \\
Colour change & No change & Brown & White-brown & Creamy \\
Smell & Very strong & Strong & --- & --- \\
Damaging effect & --- & --- & Cracks & Less cracks \\
\hline
\end{tabular}

Table II. Percentage of bone recovery.

\begin{tabular}{lcccc}
\hline Bone & $\begin{array}{c}\text { Maceration } \\
(\boldsymbol{\%})\end{array}$ & $\begin{array}{c}\text { Burial } \\
(\boldsymbol{\%})\end{array}$ & $\begin{array}{c}\mathbf{5 \%} \\
\mathbf{N a O H}\end{array}$ & $\begin{array}{c}\mathbf{3 \%} \mathbf{~ N a O H} \\
(\boldsymbol{\%})\end{array}$ \\
\hline Skull & 100 & 100 & 100 & 100 \\
Cervical vertebrae & 100 & 91 & 100 & 100 \\
Thoracic vertebrae & 98 & 95 & 98 & 100 \\
Lumbar vertebrae & 98 & 95 & 100 & 100 \\
Sacrum & 98 & 98 & 98 & 100 \\
Caudal vertebrae & 100 & 100 & 100 & 100 \\
Thorax & 95 & 78 & 91 & 94 \\
Fore limb & 45 & 33 & 73 & 82 \\
Hind limb & 64 & 51 & 78 & 87 \\
\hline
\end{tabular}

time of the bones to the solution and heat (sunlight). This study has highlighted the advantages of chemical method over maceration and burial methods in the preparation of the African Giant Pouched Rat.

ACKNOWLEDGEMENTS. All thanks goes to the staff and administration of department of anatomy, Faculty of Veterinary Medicine, Ahmadu Bello University Zaria, Nigeria.

ONWUAMA, K. T.; SALAMI, S. O.; ALI, O. \& NZALAK, J. O. Efecto de diferentes métodos de preparación ósea en el esqueleto de la rata gigante africana (Cricetomys gambianus) Int. J. Morphol., 30(2):425-427, 2012.

RESUMEN: Este estudio fue realizado en 12 ratas africanas gigantes adultas (Cricetomys gambianus) de ambos sexos, para comparar y ver el efecto de tres diferentes métodos de preparación ósea. Cinco ratas fueron utilizadas para el método de maceración, tres para el método de enterramiento y cuatro para el método químico (que implica dos ratas para solución de hidróxido de sodio al 3\% y 5\%, respectivamente). Se encontró que la preparación química con hidróxido de sodio era el mejor método en términos de tiempo requeridos para completar el procedimiento, el número de huesos recuperados, el color de los huesos y de olor de la preparación. Sin embargo, el método químico tiene la desventaja de la disolución y la formación de grietas en los huesos si la concentración utilizada es alta y no se le da el cuidado adecuado a la preparación.

PALABRAS CLAVE: Preparación ósea; Rata gigante africana; Preparación química; Maceración.

\section{REFERENCES}

Ajayi, S. S. Observations on the biology, domestication and reproductive performance of the African giant rat Cricetomys gambianus Waterhouse, in Nigeria. Mammalia, 39(9):343-64, 1975.

Borell, A. E. Cleaning small collections of skulls with dermestid beetles. J. Mammal., 19(1):102-3, 1938.

Boyle, C. Maceration and preparation of mamma skeletons for long term curation. Archaeology and forensic laboratory. University of Indianapolis, 2010.

Dawson, A. B. A note on the staining of the skeleton of cleaned specimens with Alizarin red S. Stain Tech., 1:123-4, 1926.

Ewer, R. F. The behaviour of the African giant rat (Cricetomys gambianus Waterhouse). Z. Tierpsychol., 24(1):6-79, 1967.

Grygon. Tutorial cleaning of Bones PART 1. 2010. Available in: http://fav.me/d2lxlel

Hall, E. R. \& Russell, W. C. Dermestid beetles as an aid in cleaning bones. J. Mammal., 14(4):372-4, 1933.

Perry, N. D.; Hanson, B.; Hobgood, W.; Lopez, R. L.; Okraska, C. R.; Karem, K.; Damon, I. K. \& Carroll, D. S. New invasive species in southern Florida: Gambian rat (Cricetomys gambianus). J. Mammalogy, 87(2):262-264, 2006.

The Bone Room. The Bone Room: natural history store, 2006. Available in: http:// www.boneroom.com/

Correspondence to:

Dr. Onwuama Kenechukwu Tobechukwu Department of Veterinary Anatomy Ahmadu Bello University, Zaria NIGERIA

Phone: 08036425961

Email: kenexcares@yahoo.com

Received: 08-04-2011

Accepted: 16-01-2012 